Freud, S. (1911) Psycho-analytic notes on an autobiographical account of a case of paranoia (dementia paranoides). Reprinted (1953-1974) in the Standard Edition of the Complete Psychological Works of Sigmund Freud (trans. and ed. J. Strachey), vol. XII. London: Hogarth Press.

James, W. (1902) The Varieties of Religious Experience. Reprinted (1999). New York: The Modern Library.

Jamison, K. R. (1995) An Unquiet Mind. A Memoir of Moods and Madness. New York: Knopf.

Jaspers, K. (1913) General Psychopathology. Reprinted (1962):

trans. J. Hoenig \& M. W. Hamilton. Manchester: Manchester University Press.

Lott, T. (1996) The Scent of Dried Roses. London: Penguin.

McGrath, P. (1990) Spider. London: Penguin.
Mill, J. S. (1873) Autobiography. Reprinted (1989): ed. J. M. Robson. London: Penguin.

Sass, L. A. (1994) The Paradoxes of Delusion. Wittgenstein, Schreber and the Schizophrenic Mind. Ithaca, NY: Cornell University Press.

Schreber, D. P. (1903) Memoirs of My Nervous Illness. Reprinted (1955): trans. I. Macalpine \& R. A. Hunter. London: Wm. Dawson \& Sons.

Seabrook, W. B. (1935) Asylum. London: Harrap.

Shaw, F. (1997) Out of Me. London: Penguin.

Styron, W. (1990) Darkness Visible. A Memoir of Madness. London: Cape.

Wolpert, L. (1999) Malignant Sadness. The Anatomy of Depression. London: Faber \& Faber.

\title{
INVITED COMMENTARY ON Autobiographical narrative and psychiatry
}

\author{
Lewis Wolpert
}

Oyebode (2003, this issue) suggests that autobiographical accounts of mental illness provide psychiatrists with a valuable source of information as to the nature of that condition. I am not really sure that he is right. It is hard to see what effect it has had on the treatment of patients or the understanding of mental illness. As someone who has experienced severe clinical depression, there is nothing I have read that I can recognise as corresponding to my experience, although William Styron's (1990) Darkness Visible probably comes closest. I think the problem is that, in severe depression, one enters a state that bears no relationship whatsoever to the feelings one has had in one's previous experience. This is a point well made by William James (1902). My current, rather bitter view, is that if you can describe your severe depression you have not really had one. And this may account for the almost total absence of good descriptions of depression in the classical corpus of English literature. Considering that depression affects around $10 \%$ of the population, and perhaps writers even more, it is astonishing that such descriptions are absent. Virginia Woolf, herself a sufferer from depression, did not include a description in any of her novels. It may be just too hard.

However, I have not yet read Schreber's (1955) Memoirs of My Nervous Illness, which Oyebode sees as being of singular importance. One must offer Oyebode's paper and views strong support, since psychiatrists or other mental health workers who have not personally experienced depression, for example, must have enormous difficulty understanding their patients' problems, rather like a dentist who has never had toothache. And depression is so weird that it makes life exceptionally difficult for the partner or carer of the afflicted individual. I was happily married, a professor with a fine job, and only wanted to kill myself - my wife found it somewhat intolerable. Writers have been much better at describing their own condition and Oyebode has referred to several, such as Styron and Mill. I would like to add to the list. Elizabeth Wurtzel, in her description of her depression in Prozac Nation, includes the claim that it has nothing to do with life and that she was among 'the walking, waking dead' (Wurtzell, 1995: p. 22). Tolstoy, in My Confessions (1882), described himself as healthy and happy yet suicidal - life had no meaning for him:

'The thought of self-destruction now came to me as naturally as thoughts of how to improve my life had come formerly ... and it was then that I, a man favoured by fortune, hid a cord from myself lest I should hang myself from the crosspiece of the partition in my room' (Part IV).

There is also Job from so long ago:

'Why is light given to those in misery, and life to the bitter in soul, to those who long for death that does not come, who search for it more than hidden treasure, who are filled with gladness and rejoice when they reach the grave.' 
Poets have made a major contribution, like Coleridge's Dejection, which contains:

'A grief without a pang, void, dark and drear, A drowsy, stifled, unimpassioned grief, Which finds no natural outlet or relief, In word, or sigh or tear'.

Gerald Manley Hopkins' poem 'No worst, there is none' begins:

'No worst, there is none. Pitched past pitch of grief, More pangs will, schooled at forepangs, wilder wring. Comforter, where is your comforting?'

Anne Sexton (1991) describes her state in a poem, Sickness Unto Death, which opens:

'God went out of me as if the sea dried up like sandpaper, as if the sun became a latrine.

God went out of my fingers.

They became stone.

My body became a side of mutton

and despair roamed the slaughterhouse.'

And while he is not easy to read, one should not forget Richard Burton's monumental Anatomy of Melancholy.

The deviousness of those with depression may not have been fully recognised, particularly when it comes to suicide. Many people do their best to conceal that they are in fact depressed. I know young adults who conceal it from their parents even though, in one case, the individual continually carries out self-harm and another has a father who is a psychiatrist. Oyebode shows how Kay Redfield Jamison was determined to conceal any indication of her plans to end her life. I know of a case where a young woman was determined to do so but, because of the shame that it would bring to her children, she decided to take motor bike lessons, reasoning that if she died that way it would be acceptable: fortunately she got better. This deviousness ought to be better recognised.

One of the problems for any individual with mental illness is the question of why it has happened to them. It is unlike, for example, flu or cancer, for which one can identify external causes such as viruses and toxic chemicals. Often, a mental illness is triggered by some traumatic event such as a severe loss, but it is not the cause, just the trigger. Many people suffer very severe losses and do not develop a mental illness. Yet we all try to understand the cause and tell ourselves stories that can involve both social and biological factors. There is, indeed, good evidence that genetics play a role and drugs like $\alpha$ interferon can cause depression. The reasons we give ourselves probably have little validity; I preferred, initially, to blame a drug I was taking for arrhythmia, but later depressions clearly had a psychological trigger.

Autobiographical accounts probably help others with mental illness and their carers more than the psychiatrists themselves. Patients may benefit greatly from the accounts of others with the same illness. Such accounts may also help to reduce the stigma associated with mental illness. Is it not strange that mental illness, which is a major burden on society and the effects of which must almost certainly have personally touched many members of our parliament, is rarely spoken openly about by our MPs? And again, since it is the illness our children are most likely to suffer from, should it not be at the core of health education at school, and such descriptions of mental illness being essential texts? Oyebode has opened up a topic of great importance.

\section{References}

Oyebode, F. (2003) Autobiographical narrative and psychiatry. Advances in Psychiatric Treatment, 9, 265-270. James, W. (1902) The Varieties of Religious Experience. Reprinted (1983). London: Penguin.

Schreber, D. P. (1955) Memoirs of My Nervous Illness (trans. I. Macalpine \& R. A. Hunter). London: Wm. Dawson \& Sons.

Sexton, A. (1981) The Complete Poems. Boston, MA: Houghton Mifflin.

Styron, W. (1990) Darkness Visible. A Memoir of Madness. London: Cape.

Tolstoy, L. (1882) My Confessions. Reprinted (2001). http:// classicallibrary.org/tolstoy/confessions/4.htm Wurtzell, E. (1995) Prozac Nation. New York: Riverhead.

Lewis Wolpert Professor of Biology as Applied to Medicine, Department of Anatomy and Developmental Biology, University College, London WC1E 6BT, UK. 